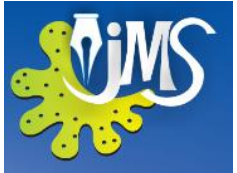

\title{
Spatial Planning for Promoting Sustainable Development in Pachchilaipalli Divisional Secretariat in the Killinochchi District of Sri Lanka- A Case Study for Post-Conflict Development
}

\author{
${ }^{1}$ Damith Chandrasekera and ${ }^{1}$ Swarna Piyasiri \\ ${ }^{1}$ Department of Zoology, Faculty of Applied Sciences, University of Sri Jayewardenepura, Sri Lanka
}

\begin{abstract}
Reconstruction and development in post-disaster or post conflict situations pose multiple challenges. These scenarios necessitate high investment for rapid reconstruction, socio-economic development to minimize future conflicts or disasters, and opportunities to introduce; landuse planning, environmental, engineering and other best practices for increased sustainability and resilience. The post-conflict situation in the Killinochchi District presents a scenario with agencies having outdated data, missing critical information, an intensive development drive which exerts pressures on nature, culture and large number of scattered development plans.

The study involves three stages, namely, establishment of baseline data, analysis of digital data and development of a zoning map as a proposed landuse. This facilitates the decision making in development activities within the area with environmnetal conservation, and coordinates stakeholder agencies for sustainable development.

The entire Killinochchi District was divided in to 92 equal grids for micro level planning and $5 \mathrm{Km}^{2}$ area in Pachchilaipalli DS Division was selected to initiate the case study. The topographical survey maps developed in 1956, 1983 and 2010 were used for spatial analysis, and to compare the landuse changes occurred during the last 57 years in the area of study. Arc GIS 10.1 software was used to develop spatial maps of different sectors. The zoning map which was prepared as the proposed landuse plan illustrates the spatial distribution of areas for development with minimum environmental impacts as the key output of the study.
\end{abstract}

KEYWORDS: Post disaster, sustainable development, spatial planning, post-conflict 


\section{INTRODUCTION}

The Killinochchi District was one of the few districts that seriously affected due to the conflict of past three decades where environment and development (similar to all other sectors) have suffered heavily. However, due to the change in security situation since May 2009 has created a safe environment whereby the Government of Sri Lanka had gained total administrative control over the conflict affected areas including the Killinochchi district. This has created a favourable climate of optimism for moving forward with plans for development of the district to produce a peace dividend to the community. Government has launched a major development thrust "Uthuru Wasanthaya (Northern Spring)" which evolves development of settlements, urban and rural infrastructure and livelihood development.

There are multiple factors which makes the situation particularly challenging. Mainly the political need of the Government to demonstrate peace dividends and implement development projects in a rapid manner in the absence of a master plan for the development of Killinochchi district. These development plans challenge the sustainable development and threatens the protection of environmental resources. The usual environmental safeguards may be ignored under such situations and unplanned development could take place. The environmental management system cannot cope up with number of projects coming up in the area. Since there are no data for past 30 years in the area due to the war situation in the district, decisions may have to be taken based on insufficient or outdated information.

Since renewal programs had started into focus on livelihood development of the economically and socially disturbed areas, it was very relevant to undertake post conflict development with environmental assessment of the present situation which is a novel concept to Sri Lanka.

Objectives

1. The objectives of the present study are to analyse the landuse data from 1956 to 2010 to find out the changes taken place particularly during war situation.

2. Using those information it is expected to develop a zoning map as a propose landuse plan to use for future development activities as a piece of Master Plan.

Therefore the purpose of this study was to understand the probable environmental consequences arised due the prolong conflict scenario and to introduce spatial solution to facilitate post conflict sustainable development in the area of study. The assessment focused to avoid development in environmentally sensitive or disaster-prone areas and to manage and control unplanned development whilst proposing suitable landuse to initiate national development goals. This assessment will help to avoid adverse impacts arising from implementation of unplanned development activities. It helps to introduce sustainable landuse planning, mitigatory measures to ensure environmental conservation and implement monitoring framework to facilitate disaster management for economic development and district planning. It will also facilitate and strengthen the sustainable development and environmental conservation process by helping policy makers and planners to take early account of the environmentally sensitive and disaster prone areas.

\subsection{Area of Study}

The specific geographical area of this research is limited only to a $5 \mathrm{Km}^{2}$ grid area in Pachchilaipalli Divisional Secretary in the Killinochchi district (Figure 1). The area is administratively covered by 5 GN divisions 
namely Pullopalai, Pulopallai West, Pallai Town, Thampakamam and Mullaiyadi.

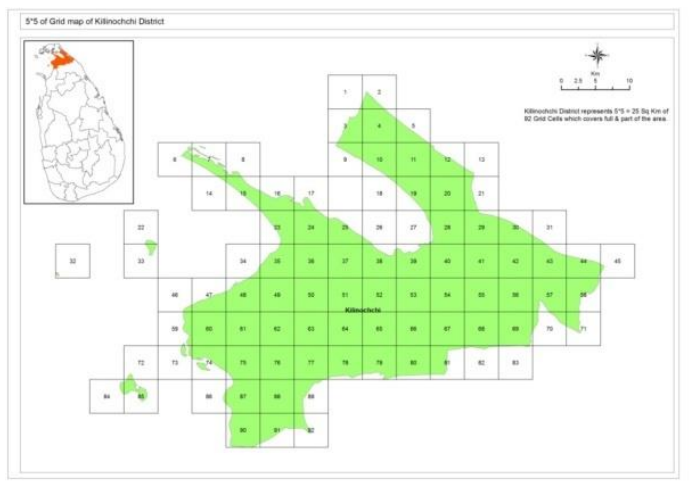

Figure 1. Geographical scope of the study in Killinochchi District. Source: 1:50000 Survey Map

The area covered by the study falls within the dry zone of Sri Lanka where tropical dry climate is prevalent. The entire district together with the area of study receives a low rainfall throughout the year. The mean annual temperature is about $30-34^{\circ} \mathrm{C}$.

Physiographically, the area covered by the Kilinochchi district belongs to the lowest peneplain of Sri Lanka. Topography of the entire District is very low and featureless, with elevations generally less than $10 \mathrm{~m}$ a.m.s.l., Even though the Killinochchi district is largely covered by the red-yellow latosol soil, as depicting in figure 2, the soil type of the area of study is mostly covered with regosols.

According to statistics, the majority of population in the District as well as in the area of study is engaged in crop farming and over 45 percent of the labour force directly depends on agriculture for their livelihood. The District has accounted for a major share of the agricultural output since the district was a major supplier of subsidiary food crops such as onion and chilies.

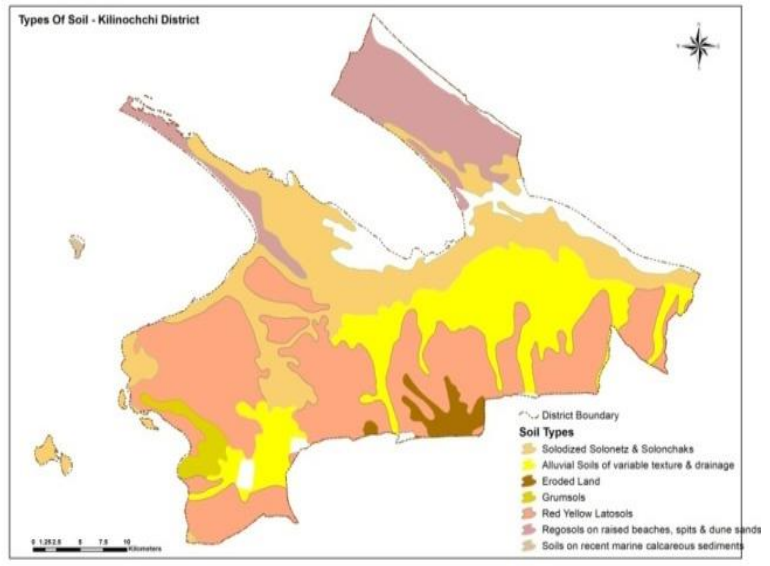

Figure 2.Type of Soil in Killinochchi District

Source: ISEA - North, 2010

\section{MATERIALS AND METHODS}

The study was conducted with multisector consultation and analysis in three phases, namely (a) baseline phase, (b) field survey and development phase, and (c) assessment phase.

Then the spatial analysis was done in order to prepare the final output maps

\subsection{Phases of Study}

\section{(a) Baseline Phase}

The first step of the study was to compile the baseline information. The baseline data under sectors of nature, water and culture were collected. Resource mapping was undertaken through primary and secondary data collected and compiled during this phase. The information available in published forms and those with the state agencies on environmentally sensitive areas were used as secondary data with 'ground truthing' where possible. The gap filling carried out with the assistance of key technical agencies.

\section{(b) Development Phase}


Respective agencies were consulted under the development phase to map the proposed development plans. In this process, District Secretary and district planning unit were consulted to incorporate the development plans and to share information on the process and intermediate products of the study. These development plans were incorporated to the resource map.

\section{(c) Assessment phase}

The key stakeholder agencies who were involved in conservation and development activities at local and central level were consulted to identify potential development scenarios, conflicts and mitigatory measures to overcome them. The assessment phase led to the spatial analysis and development of proposed landuse map (zoning Map).

\subsection{Spatial Analysis}

The digital data required to analyse the demographical and geographical characteristics in the area of study were obtained from the Survey Department. The topographical survey maps scale 1: 63360 (one inch to one mile) developed in 1956 were digitized and series of topographical survey maps in the scale of 1:50000 publishedin 1983 and 2010 were used to compare and find the landuse changes occurred during the last 57 years in the area of study. Further topographical maps at the scale of 1:10000 published by the Survey Department in 2010 were used for spatial analysis and presentation. The maps include the characteristics of landuse, transport, hydro and buildings. Further latest google earth spatial maps were used for comparison and ground verifications. Arc GIS 10.1 package was used in the data analysis. The entire district was divided in to 92 grid cells at a dimension of $5 \mathrm{Km}^{2}$ for micro level planning (Figure 1).

\section{RESULTS AND DISCUSSION}

The survey maps developed in 1956 (1 inch) depicted below as figure 3, 1983 (figure 4) and $2010(1: 50000 / 1:$ 10000) shown as figure 5 and 8 were used to compare the potential landuse changes and landuse practices taken place over last 56 years in the area of study. Those three maps represent equal intervals of 27 years each from 1956 to 2010. Further the satellite image of 2013 shown as figure 6 was used to verify the landuse changes of the study area.

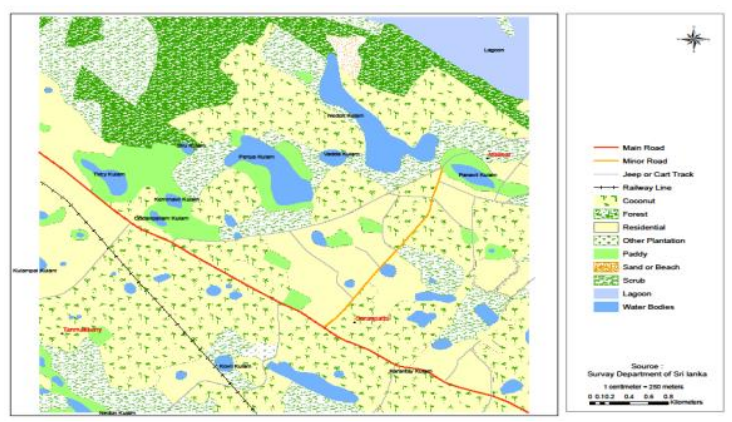

Figure 3. Landuse of $5 \mathrm{~km}^{2}$ grid selected in Pachchilaipalli DS Division. Source: 1: 63360 (1956) Survey Map

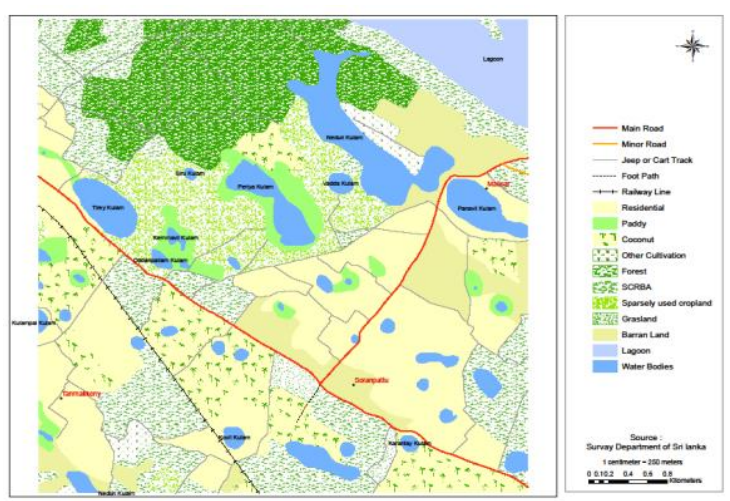

Figure 4. Landuse of $5 \mathrm{~km}^{2}$ grid selected in Pachchilaipalli DS Division Source: 1:50000 (1983) Survey Map 

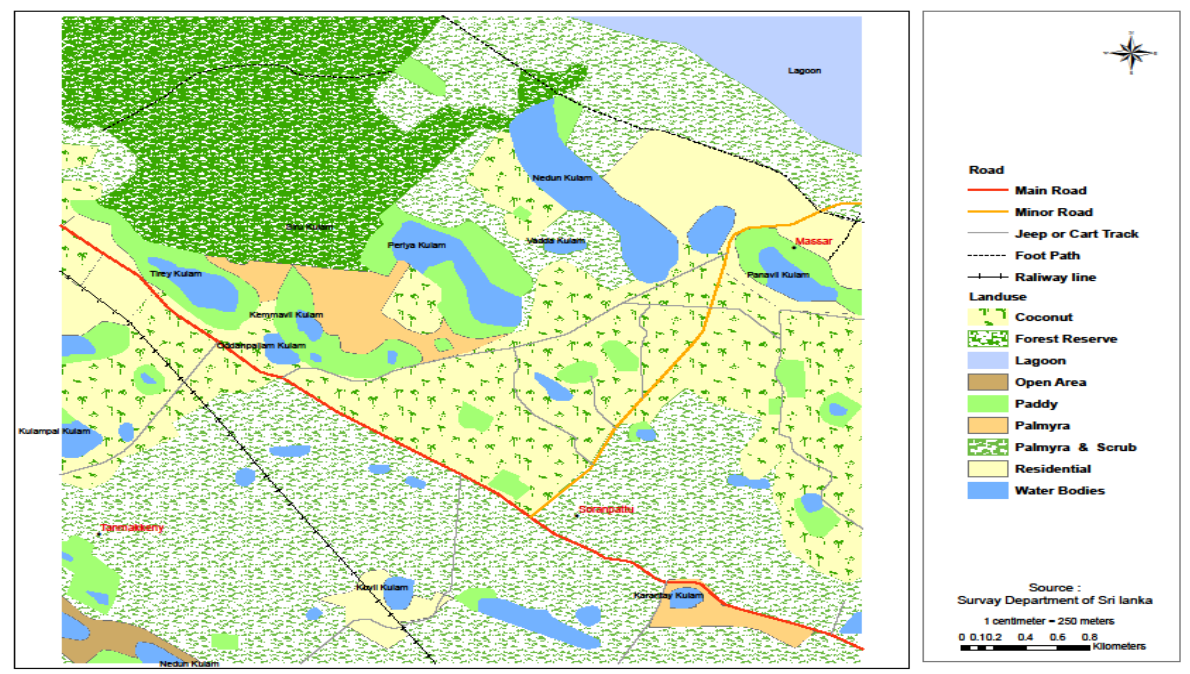

Figure 5. Landuse of $5 \mathrm{~km}^{2}$ grid selected in Pachchilaipalli DS Division Source: 1:50000 (2010) Survey Map

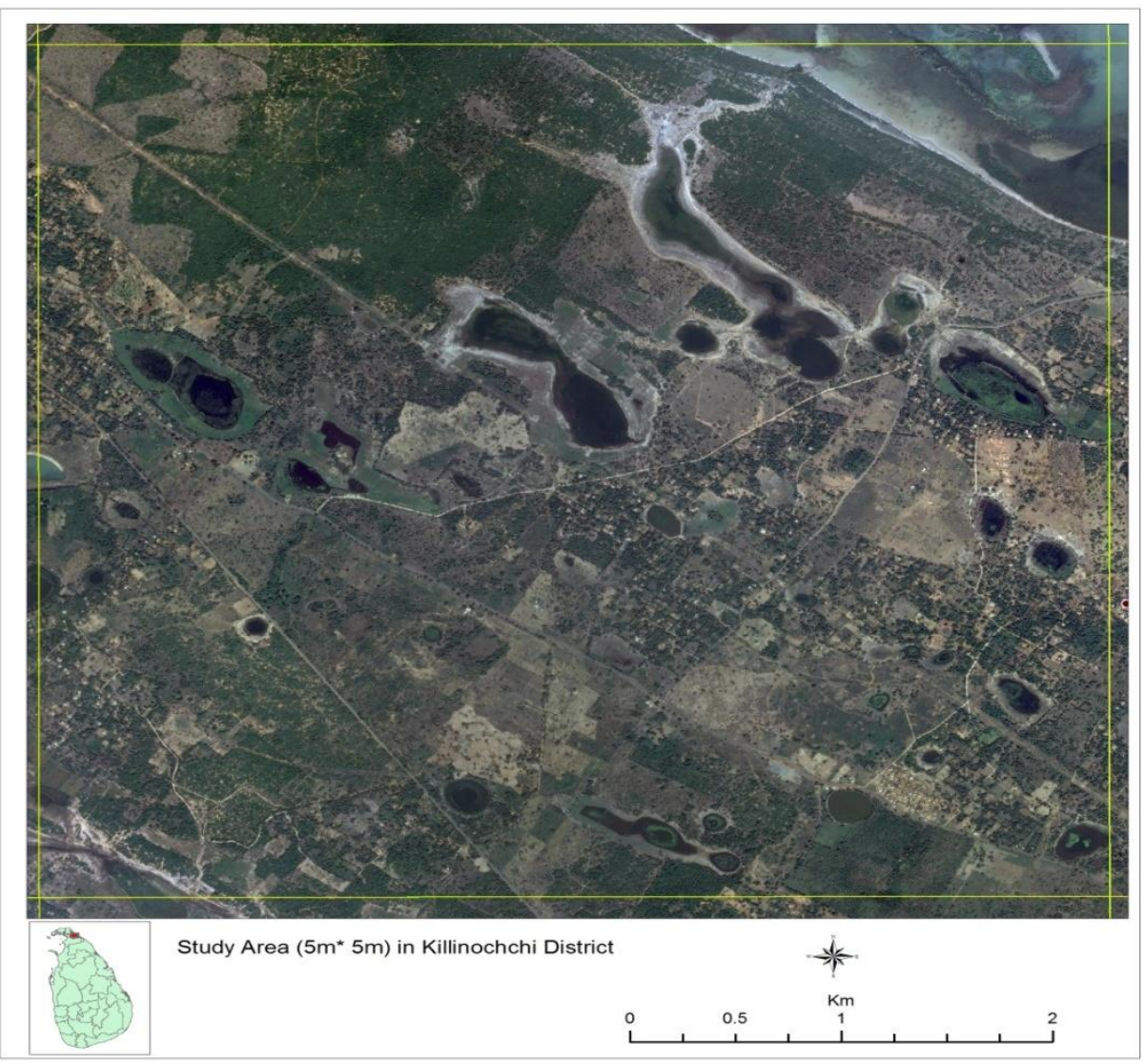

Figure 6. Satellite image of $5 \mathrm{Km}^{2}$ grid selected in Pachchilaipalli DS Division

Source: Satellite image -2013 
The comparison of three spatial maps (Figure 3,4 and 5) clearly indicates that certain landuse types were increased and some types were relatively decreased. The landuse type changes are indicated in figure 7 .

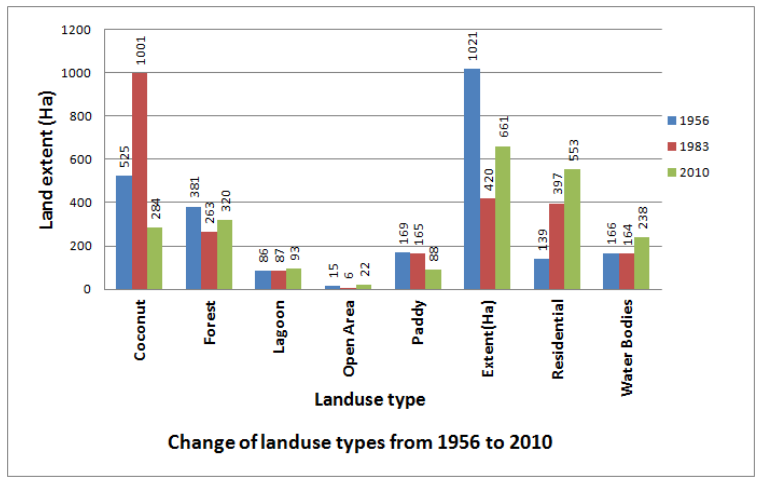

Figure 7. Change of Landuse types (1956 - 2010)

As illustrated in Fig 7, the total land extent of coconut cultivation was drastically dropped from 1001 to $284 \mathrm{Ha}$ ( by 717 hectare) within the period from 1983 to 2010 .

The area of forest had reduced by 118 hectare within the period from 1956 to 1983 , as the area of forest was utilised for plantation crops, but it has regained nearly the same extent by 2010 .

The extent of paddy during the period from 1956 to 1983 has no major difference but since 1983 the situation has changed and presently the area of paddy had decreased by 77 hectare (165 hectare to 88 hectare) which is almost $50 \%$ drop of land area.

The area for Residential area (homestead) has indicated an increase of 258 hectare during the period from 1956 to 1983 but the same had decrease by 156 hectare within the period from 1983 to 2010. The changes recorded in other landuse types are only marginal and are insignificant.

The landuse within the period from 1956 to 1983 provides clear indication of extensive utilisation of land for agricultural and other livelihood purposes. The result illustrates a significant drop of utilisation of land for agriculture from 1983 - 2010, specially coconut, paddy and palmyra which are major agricultural products of the area. The fact is further strengthened with the evidence of an increasing trend of scrub land and forest extends after 1983. Further latest spatial images as indicated in figure 6 confirm that the areas used for plantations and agriculture had transformed into scrubs and new forest areas. A considerable decline of homestead is highlight after 1983 and the utilisations of land for other purposes were also in a declined state.

As a whole, it is understood that the people of the area had migrated at large to other parts of the country due to the prolong war since 1983 and even the movements of the people living within the area of study would have been restricted due to unsafe mobility and security reasons. Even though the livelihood and living condition of the people living in were considerably affected, the level of environmental degradation was found to be at minimal level as most of the environmental conservation indicators remain at a satisfactory standard.

The present landuse at the scale of 1:10000 (figure 8) was used for spatial analysis and presentation. Considering the landuse records since 1956 and scientific data, an appropriate landuse was proposed as mentioned in table 1 and same is presented in figure $9 \& 10$.

\section{Zoning Map}

The area of study was divided into six zones (figure 11) as follows, in order to plan for optimal utilization of existing land to maximise the productivity of land in line with National and regional development programmes - Vision for the Future first and second 5 year development framework, 
Unstoppable Sri Lanka - 2020 and (2020), National Physical Plan - 2030, Uthuru Wasanthaya Programme etc.
a. Commercial Zone
b. Agricultural Zone
c. Industrial Zone
d. Tourism \& Recreational Zone
e. Protection/conservation Zone and,
f. Residential Zone

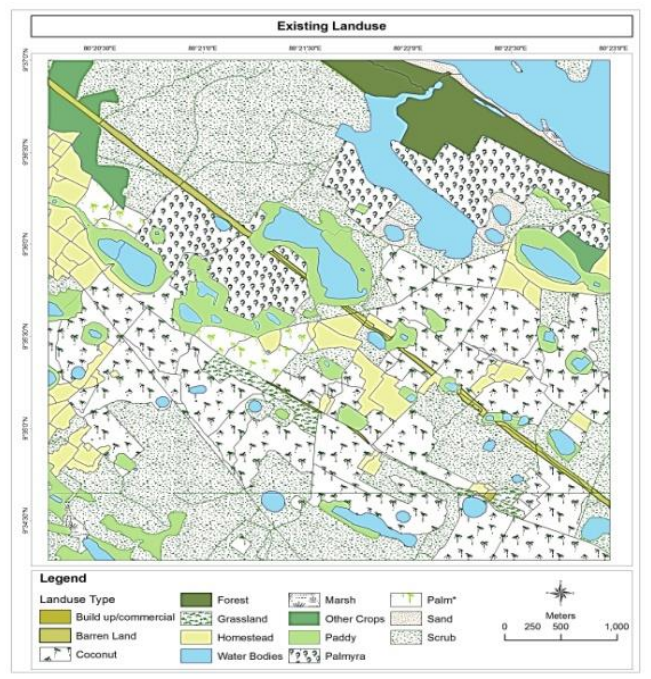

Figure 8. Existing landuse of $5 \mathrm{Km} 2$ grid selected in Pachchilaipalli DS Division. Source: Survey Maps

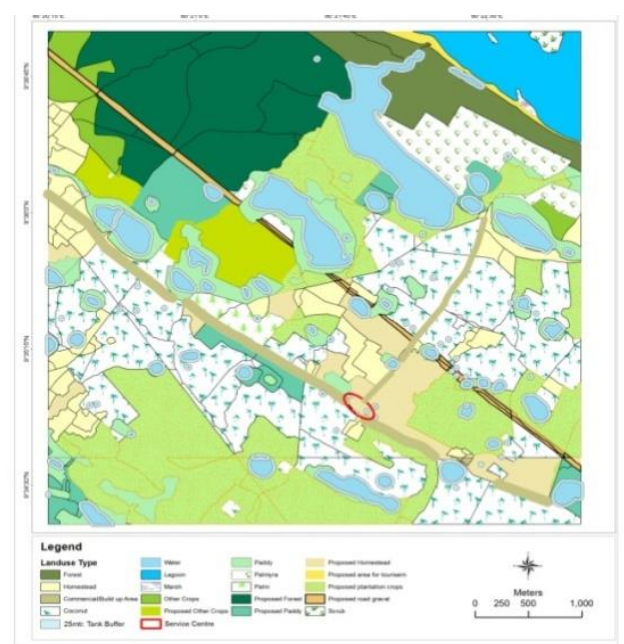

Figure 9. Proposed landuse of $5 \mathrm{Km}^{2}$ grid selected in Pachchilaipalli DS Division. Source: Survey Maps

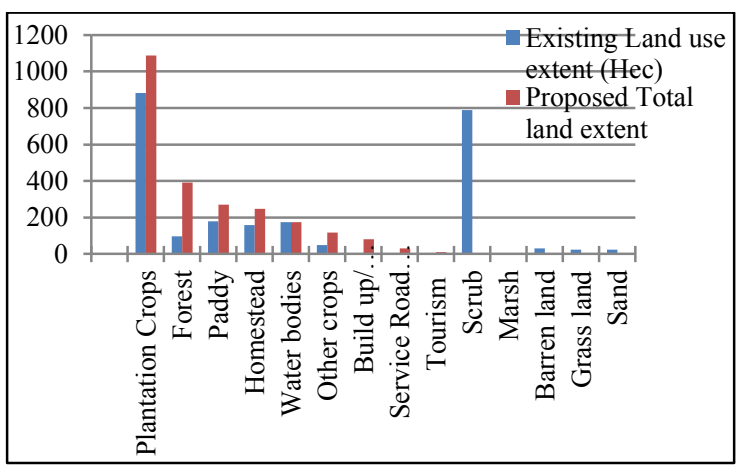

Figure 10. Existing vs proposed landuse of $5 \mathrm{Km}^{2}$ grid selected in Pachchilaipalli DS Division

Total 14 sectors were analysed within the period of 57 years from 1956. Zoning was done considering the landuse in 1956, 1983 and 2010 .

The zoning was focused to facilitate the development with minimum environmental impacts. Further study considered to improve the socio economic status and livelihood opportunities of the community living in the area of study.

\section{(a) Agricultural Zone}

The plantation crops such as coconut, palmyra and palm are the three main plantation crops representing the landuse in the area of study. These plantation crops cover about $36 \%$ of the total land area. Out of plantation crops coconut was found to be covering the major land extent of $71 \%$ and palm has the minimum coverage of 5.41 ha. Since the district is located in low country dry zone with red-yellow latosols and regosols soil and the species represent the same family, these plantation crops are more suitable for plantation in the area of study.

Further the historical landuse records since 1956 also proves the fact as large extent of the area was utilized for plantation of these crops. 
Table 1. Proposed landuse change of $5 \mathrm{~km}^{2}$ grid area selected in Pachchilaipalli DS

\begin{tabular}{|l|l|l|l|}
\hline Category & $\begin{array}{l}\text { Existing } \\
\text { Landuse extent } \\
\text { (ha) }\end{array}$ & $\begin{array}{l}\text { Propose land } \\
\text { extent (ha) }\end{array}$ & $\begin{array}{l}\text { Landuse change } \\
\text { (ha) }\end{array}$ \\
\hline Build up/ Commercial area & 0.65 & 79.94 & 79.29 \\
\hline Barren land & 29.89 & 0.00 & -29.88 \\
\hline Service Road gravel & 0.00 & 29.88 & 29.88 \\
\hline Plantation Crops(Coconut, Palmyra, Palm) & 882.68 & $1,089.01$ & 206.33 \\
\hline Forest & 97.95 & 390.57 & 292.62 \\
\hline Grass land & 24.35 & 0.00 & -24.35 \\
\hline Settlement & 157.84 & 247.04 & 89.20 \\
\hline Water bodies & 175.11 & 175.11 & 0.00 \\
\hline Marsh & 5.97 & 1.81 & -4.16 \\
\hline Other crops & 48.55 & 117.46 & 68.90 \\
\hline Paddy & 180.11 & 270.37 & 90.26 \\
\hline Sand & 24.33 & 0.00 & -24.33 \\
\hline Tourism & 0.00 & 10.47 & 10.47 \\
\hline Scrub & 789.64 & 5.41 & -784.22 \\
\hline Total & $2,417.06$ & $2,417.06$ & 0.00 \\
\hline
\end{tabular}

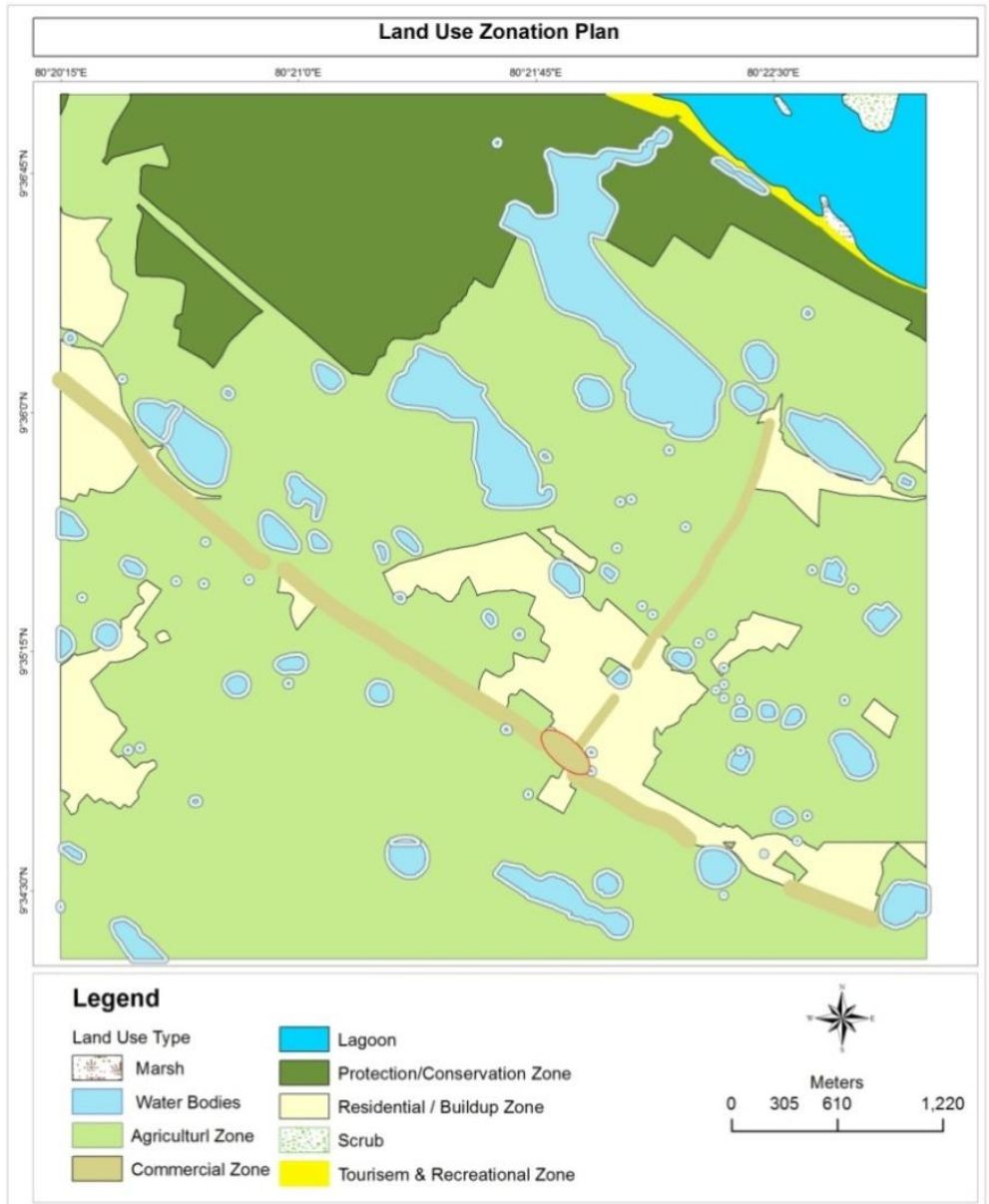

Figure 11. Zone Map - Proposed landuse zoning for $5 \mathrm{~km}^{2}$ grid area selected in Pachchilaipalli DS Division. Source: 1:10000 Survey Map, 2010 
Since coconut is a perennial crop which use only $25 \%$ of the soil, there is a great potential for growing other crops as intercrops and to promote animal husbandry under these plantation areas.

Table 2. Forecast for plantation crop expansion in the area of study

\begin{tabular}{|l|l|l|l|}
\hline $\begin{array}{c}\text { Type of } \\
\text { Crop }\end{array}$ & $\begin{array}{c}\text { Present } \\
\text { extent- } \\
2010 \text { (ha) }\end{array}$ & $\begin{array}{c}\text { Forecast } \\
\text { (ha) }\end{array}$ & \multicolumn{1}{c|}{$\%$} \\
\hline Coconut & 626.8927 & 773.43 & 71.02 \\
\hline Palmyra & 207.9907 & 256.61 & 23.56 \\
\hline Palm & 47.7916 & 58.96 & 5.41 \\
\hline Total & 882.675 & 1089.01 & 100.00 \\
\hline
\end{tabular}

Source: 1:10000 Survey Map, 2010

The land extents of paddy and other crops sectors were also proposed to increase in order to expand the agricultural areas and to improve the productivity of land use. Seasonal and field crops such as chilies (green), black gram, red onions, groundnuts and potatoes etc. are proposed in line with 2020 development plan.

\section{(b) Conservation Zone}

Study propose 292 hectare increase of forest land since the identified new area for conservation is physically covered with dense forest and found to be marginally changed during last five decades. This fact is further strengthened by the satellite images and one inch landuse in 1956. Due to the increase in population and utilisation of forest for plantation agriculture, an extent of $63 \%$ forest area was reduced within the period from 1956 to 1983 , but subsequently the area had increase considerably.

The study area consists 90 minor tanks/waterholes which count for about 175 hectare. Each water body was proposed with a 25 meter buffer zone in order to protect the minor tanks/waterholes from encroachments.
The total area for the buffer zones is 98.75 hectare.

\section{(c) Residential Zone}

Considering the increasing trend of population and their livelihood activities, the total land extent for homestead is proposed to increase by 89 hectare. This is mainly for housing, promote home gardens and open space cultivation including fruit trees such as grapes and wood apple and small holdings of coconut and palmyra.

Further animal husbandry and broiler farms could be promoted to increase the backyard economy of households.

\section{(d) Commercial/Build up Zone}

The commercial /build up area is proposed to be increased from 0.65 hectare to 79.29 hectare. Under this study, this sector was given the highest percentage of land allocation than other sectors in order to facilitate the development whilst ensuring environmental conservation. The area proposed for future residential (including guest houses), commercial, institutional, administrative, transportation, small and medium scale industries and urban open spaces etc. Central, regional or other sublevel development plans in the area of interest were not reported.

\section{(e) Industrial Zone}

Since the government has planned to upgrade and modernize the Achchuvali Industrial Estate in Jaffna, major scale industries were not proposed. Further the area is not suitable for major industries as the area is more of agricultural based, environmentally sensitive and short of required infrastructural facilities. Since the area of study consist 90 minor tanks/waterholes which covered around 175 
hectare, it is proposed to promote inland fishery as an activity of livelihood.

\section{(f) Tourism and Recreational zone}

According to the ISEA 2010 study, the area is enriched with forest, lagoon and wildlife including sea and wilding birds. An area of 10.47 hectare adjoining the lagoon and forest was proposed to promote ecotourism targeting local and foreign tourist. Most of the sand areas have been proposed to be utilized for the purpose.

The land identified as barren was found to be an uncropped road track. The total area proposed as a gravel road to be used as a service road for the maintenance of inland water bodies and access road to agricultural areas. The remaining areas under marsh and scrubs are found to be located in the lagoon which could not be utilised for any productive purpose. Extents of following unproductive/underutilized lands were proposed to be reduced as indicated in Table 3.

Table 3. Existing landuse proposed to reduce

\begin{tabular}{|l|l|l|}
\hline Category & $\begin{array}{l}\text { Existing Land } \\
\text { area (ha) }\end{array}$ & $\begin{array}{l}\text { Total propose } \\
\text { land extent } \\
\text { (ha) }\end{array}$ \\
\hline Barren land & 29.89 & 0.00 \\
\hline Grass land & 24.35 & 0.00 \\
\hline Marsh & 5.97 & 1.81 \\
\hline Scrub & 789.64 & 5.41 \\
\hline
\end{tabular}

Source: 1:10000 Survey Map, 2010

As per the ISEA 2010 and the Hazard Profile of Sri Lanka, the area of study found to be free from hazards such as floods and coastal hazards which are common to most of the other parts of the Killinichchi district. According to ISEA 2010 the area of study is vulnerable to drought and high winds as the total land area of Killinochchi distract is within the very high drought vulnerable zone and classified under "zone one" in the wind loading study conducted after the East coast cyclone in 1979.

\section{CONCLUSIONS \& FUTURE RESEARCH}

Due to the 30 years prolong war, the area of study was adversely affected in all aspects especially the physical and socio-economic development of the people who were living in the area of study were totally hampered. Therefore it is necessary to initiate development activities that were lag behind many years in a rapid and sustainable manner. At present development in Killinochchi district is taking place in rapid manner and it is essential to introduce a sustainable mechanism to achieve longlasting development covering all segments of the society.

The study examined the spatial evolution of landuse changes at the contexts of pre, during and post conflict periods of the last 30 years within a pilot study area of $5 \mathrm{~km}^{2}$ grid area in Pachchilaipalli Divisional Secretary in the Killinochchi district (Figure 1).

As per the methodology, the study compared the changes in landuse in three different intervals from 1956 to 2010. Results showed a significant decline trend of population and related livelihood activities in the area of study due to the eruption of hostilities in 1983 and continued until cessation of conflict in 2009. Further, analysis indicates expansion of forest areas within the period of conflict. The study highlighted the effects of war on productive land, where most of the lands which were productive during the period from1956 to 1983 were transformed in to infertile land by 2010. 
The results provided a better understanding of the impact of 30 years of conflict in the study area. Although it was known in an anecdotal sense that impact of war had adversely affects on many sectors, the present analysis is unique in defining those effects in spatial terms, in showing its extent of change in landuse.

The future analysis on the area of study could grant an opportunity to validate the proposed landuse changes and the results of this study. This study can be particularly useful for district planning as a guide during strategic decision making and to identify suitable lands for future development activities.

The study intends to replicate in other 91equal slots covering the whole Killinochchi district and finally to prepare the district land use zoning map to facilitate future sustainable development in the Kilinochchi district.

\section{REFERENCES}

BRACKHAHN, B., \& KÄRKKÄINEN, R. (EDS.). Spatial Planning as an Instrument for Promoting Sustainable Development in the Nordic Countries: Action Programme for 2001-2004. Ministry of Environment, Denmark. 2001.

CENTRAL ENVIRONMENTAL AUTHORITY. Integrated Strategic Environmental Assessment, Northern Province of Sri Lanka. 2014.

CENTRAL ENVIRONMENTAL AUTHORITY. Integrated Strategic Environmental Assessment, Northern Province of Sri Lanka: Map Atlas. 2014; 0146.

CENTRAL AUTHORITY. Strategic Environmental Assessment for Greater Hambantota Development Plan. 2010;10-36.
DISASTER MANAGEMENT CENTER, MINISTRY OF DISASTER MANAGEMENT. Hazard Profile of Sri Lanka. 2012; 47 - 86, 105- 225.

DEPARTMENT OF NATIONAL PLANNING. Public Investment Strategy: Unstoppable Sri Lanka -2020. 2013; 47 119.

DEPARTMENT OF NATIONAL PLANNING. Vision for a New Sri Lanka: Ten Year Horizontal Development Policy Frame work, Discussion Paper - 2006 2016. 2005; 50-124.

MINISTRY OF CONSTRUCTION, ENGINEERING SERVICES: HOUSING AND COMMON AMENITIES. Physical Plan for the Northern Province. 2012; 1: 14-78.

NATIONAL PHYSICAL PLANNING DEPARTMENT. National Physical Planning Policy and Plan Sri Lanka -2030. 2006; 67$68,73-83$.

ORGANIZATION FOR ECONOMIC COOPERATION \& DEVELOPMENT. Strategic Environmental Assessment and Post-Conflict Development. 2010; 5-14

STEAD D. Spatial planning: key instrument for development and effective governance with special reference to countries in transition. 2008.

THE CLIMATE CHANGE SECRETARIAT OF SRI LANKA. Retrieved 15 Jan 2015 from hhttp://www.climatechange.lk

/ccs_index.html

UNITED NATIONS DEPARTMENT OF ECONOMIC AND SOCIAL AFFAIRS DIVISION FOR SUSTAINABLE DEVELOPMENT. Developing National Sustainable Development Stratergies in Post Conflict Countries. 2012; 44-64. 